\title{
Measuring Customers' Satisfaction Regarding Different Services of Mobile Telecom Operator Companies in Bangladesh: An Evaluation
}

\author{
Md. Omar Faruk Sarker ${ }^{1}$, Taposh Kumar Neogy ${ }^{2 *}$ Farzana Akhter $^{3}$ \\ ${ }^{1}$ Associate Professor, Department of Marketing, University of Rajshahi, Rajshahi - 6205, BANGLADESH \\ ${ }^{2}$ Assistant Professor (Accounting), Institute of Business Administration (IBA), Rajshahi (under National \\ University), BANGLADESH \\ ${ }^{3}$ Lecturer (English), Institute of Business Administration (IBA), Rajshahi (under National University), \\ BANGLADESH \\ *Corresponding Contact: \\ Email: neogyais@ gmail.com \\ Phone: +88-0721-750166
}

\begin{abstract}
The purpose of the present research study is to measure the customer satisfaction regarding the different services of the mobile telecom operator companies in Bangladesh. The mobile telecom sectors are growing rapidly and the contribution of this sector to economic development is very significant. The study surveyed 150 users' opinions to determine the satisfaction level regarding the different services of the mobile telecom operator companies in Bangladesh. On the basis of findings it is evident that the most of the respondents opined that they are moderately satisfied of getting the different services of the mobile telecom operator companies in Bangladesh. This study also revels that there is no significant difference of opinions among the respondent regarding getting the different services of the mobile telecom operator companies in the most of the cases.
\end{abstract}

Keywords: Customers' Satisfaction, Services, Mobile Telecom Company, Bangladesh

9/10/2015

Source of Support: Nil, No Conflict of Interest: Declared

How to Cite: Sarker M. O. F., Neogy T. K. and Akhter F. 2015. Measuring Customers' Satisfaction Regarding Different Services of Mobile Telecom Operator Companies in Bangladesh: An Evaluation ABC Journal of Advanced Research, 4, 115-128.

This article is is licensed under a Creative Commons Attribution-NonCommercial 4.0 International License. Attribution-NonCommercial (CC BY-NC) license lets others remix, tweak, and build upon work non-commercially, and although the new works must also acknowledge \& be non-commercial.

\section{INTRODUCTION}

At present the world is the world of information and technology. Mobile telecom is the important wonder of the modern science. The mobile telecom has enriched the total communication network in Bangladesh. Currently the communication is very much essay from one corner to another through using the mobile telecom service. Mobile telecommunication companies have emerged as an important economic sector at present time and it is adding a lot in boosting up the economy of Bangladesh. The mobile telecommunication companies in Bangladesh are aiming at providing cost effective and quality services to the customer (Neogy, 2014). Mobile telecom service is keeping important role in 
removing the digital divide. The users of mobile telecom in Bangladesh are increasing rapidly and the total number of subscribe of the different mobile telecom operator companies have reached 121.860 million at the end of January 2015 (BTRC). For increasing the subscribes rapidly of the mobile telecom companies, the customers are important. People in Bangladesh are becoming busy day by day and more professional than previous. They need to share more information to each other because demography has changed due to the era of globalization. Mobile phone has introduced a tremendous change in the communication sector in our country. Telecommunication operators' market has a great potentiality because mobile phone in Bangladesh has become as part of the country's culture from upper class to lower class in connecting and making communication with the nearest ones or the associated through mobiles. It has become a very popular communication medium because business people, professional persons, even students are using this products intensively for their personal and occupational purposes (Ashaduzzaman, Ahmed and Khan, 2011). In Bangladesh due to increase in the mobility and emerging complex business environment people are moving from one place to another. Therefore, they want to talk with the connected people for taking the right decision at the right time during their movement. So in a country like Bangladesh where the land line is very hard to come by most of the consumers now-a-days depend on cell phone to communicate with each other. In recent times mobile telecom operators play an important role which enhance social interactions between and among individuals, groups, organizations, and the governments alike and which ultimately create a strong network of global environment (Rahman, 2012). The people of Bangladesh are now dreaming of a digital Bangladesh. Faster development of telecommunications network coupled with improved quality of service in line with the national development is a must for the fulfillment of the vision and aspiration of digital Bangladesh and also to take her to a position of honor in the country of nations in the $21^{\text {st }}$ century. Mobile phone operators have been playing an important role in this regard (Rahman, 2010). The role of the mobile telecom operator companies is important for improving the standard of life and it already has become an important part of our life. The mobile telecom operator companies are service oriented and the customer satisfaction is very much essential matter of every mobile telecom operator companies. Customer satisfaction is most important for the survival and the success of a company. Customer satisfaction is long term agenda of every mobile telecom companies. Without the customer's satisfaction, the mobile telecom operator companies can not run long term with successfully. Customers' satisfaction depends on the different services which present the mobile telecom operator companies for their customers. The mobile telecom sector is very much competitive. Competition in this industry intensifies the urgency of making customer satisfied for corporate profitability and survival in a competitive marketplace (Rahman, et. al., 2014). The state of satisfaction depends on a number of both psychological and physical variables, which correlate with satisfaction behaviors. The level of satisfaction can also vary depending on other options the customer may have and other products against which the customer can compare the organizations product. Customers' satisfaction has now become major concern of the mobile service providers in our country (Hossain, Hossain and Siddikee, 2012). The telecom services have been recognized the world-over as an important tool for socio-economic development for a nation. It is one of the prime support services needed for the rapid growth and modernization of various sectors of the economy. Economy becomes handicapped in the absence of a sound telecom network system. The quality of services provided are directly proportional to the customer satisfaction and word of mouth as each customer generally compares the tangible services with their own expectations and it the tangible on falls below their expectations, the customers generally is disappointed and that affects his loyalty towards the company (Yadav and Dabhade, 2013). Customer satisfaction can 
provide you with major competitive advantages, which can directly lead to increase in profitability and growth of business (Sheth, 2001). Bangladesh enters the mobile telecom world through the Citycell (Pacific Bangladesh Telecom Limited) in 1993. At present there are six mobile telecom operator companies in Bangladesh.

The mobile telecom operator companies have become the symbol for positive change in Bangladesh. Banglalink Digital Communication Limited (previously orascom telecom Bangladesh limited) is fully owned by Telecom Ventures Ltd. (previously orascom telecom ventures limited) of Mata. Banglalink is a brand name and it lunched in February 2005. Banglalink is the second largest mobile telecom provider company in Bangladesh and it currently has reached 31.145 million subscribers at the end of January 2015 (BTRC). Banglalink changed the mobile phone status from luxury to a necessity, brought mobile telephone to the general people of Bangladesh and made a place in their hearts. Banglalink understands people's need best and create and deliver appropriate communication services to improve people's life and make it simple. Banglalink believe in its uncompromising committed to fulfill its customer need and satisfaction and to become their first choice in telecommunication (Website of Banglalink). Again Robi Axiata Limited is a joint venture company between Malaysia and Japan. It was formerly known as Telekom Malaysia International (Bangladesh) which commenced operation in Bangladesh in 1997 with the brand name Aktel. On 28 March 2010, the service name was rebranded as Robi. Robi is the third largest mobile telecom operator company in Bangladesh and the number of subscribes have reached 26.283 million at the end of January 2015 (BTRC). Robi is the most dynamic and rapidly-growing telecommunication operator company in Bangladesh, in developing its services to meet increasing customer needs- ranging from voice and high speed internet services to tailor-made telecommunication solutions. Robi is committed to provide best data and voice quality and continue to ensure that its customers are able to enjoy the best experience through leading edge technology and innovative products and services. Robi is truly a people-oriented brand of Bangladesh. Robi, the people's champion, is there for the people of Bangladesh, where they want and the way they want. Robi creates distinct services with local flavor to remain close to the hearts of its customers (Website of Robi).

\section{ObJectives OF The Study}

The main objective of the study is to evaluate the customers' satisfaction of mobile telecom operator companies in Bangladesh regarding the different services.

\section{HyPOTHESES OF THE STUDY}

The present research study has developed and tested the following hypotheses:

$\mathrm{Ho}_{1}$ : There is no significant difference of opinions among the respondents regarding the connection fees of the sample mobile telecom operator companies.

$\mathrm{Ho}_{2}$ : There is no significant difference of opinions among the respondents regarding the call rate of the sample mobile telecom operator companies.

$\mathrm{Ho}_{3}$ : There is no significant difference of opinions among the respondents regarding the network facility of the sample mobile telecom operator companies.

$\mathrm{Ho}_{4}$ : There is no significant difference of opinions among the respondents regarding the various offers of the sample mobile telecom operator companies.

$\mathrm{Ho}_{5}$ : There is no significant difference of opinions among the respondents regarding the balance transfer system of the sample mobile telecom operator companies. 
$\mathrm{Ho}_{6}$ : There is no significant difference of opinions among the respondents regarding the FnF system of the sample mobile telecom operator companies.

$\mathrm{Ho}_{7}$ : There is no significant difference of opinions among the respondents regarding the billing system of the sample mobile telecom operator companies.

$\mathrm{Ho}_{8}$ : There is no significant difference of opinions among the respondents regarding the service system of customer care centre of the sample mobile telecom operator companies.

Hog: There is no significant difference of opinions among the respondents regarding the connection charges of internet service of the sample mobile telecom operator companies.

\section{Methodology of the Study}

At present six mobile telecom operator companies are working in Bangladesh and researchers have been selected two mobile telecom operator companies such as Banglalink Digital Communication Limited and Robi Axiata Limited for the purpose of the present research study. The present research study is based on both primary and secondary data. Primary data have been collected from the users through structure questionnaire. The questionnaire contains 15 questions. The users consist of student, business man and services holder. Researchers have been selected 150 respondents and these respondents consist of 50 students, 50 business man and 50 services holders. Secondary data have been collected from the published annual reports. Researchers have been used five point Likert scale like highly satisfied $=5$, moderately satisfied $=4$, partly satisfied $=3$, neutral $=2$ and dissatisfied $=1$ for measuring the opinions of the selected respondents regarding the various services of the sample mobile telecom operator companies in Bangladesh. Researchers also have used the chi square test and ANOVA test for testing the developing the different hypotheses for the present research study. The symbol of Chi-square is $\chi 2$.

\section{Testing of Hypotheses, Major Observations and Findings}

In this section researchers have analyzed the opinions of the selected respondents and testing the hypotheses. Researchers also presented the findings of the present research study.

Table No 1: Table showing the opinions of the respondents regarding the connection fees of the sample mobile telecom operator companies

\begin{tabular}{|c|c|c|c|c|c|c|c|c|}
\hline & \multicolumn{9}{|c|}{ Respondents } & \multicolumn{2}{c|}{ Total } \\
\hline & \multicolumn{2}{|c|}{ Student } & \multicolumn{2}{c|}{ Business Man } & \multicolumn{2}{c|}{ Service Holder } & \multicolumn{2}{c|}{} \\
\hline & Frequency & $\%$ & Frequency & $\%$ & Frequency & $\%$ & Frequency & $\%$ \\
\hline Highly Satisfied & 18 & 36.00 & 11 & 22.00 & 22 & 44.00 & 51 & 34.00 \\
\hline Moderately Satisfied & 26 & 52.00 & 32 & 64.00 & 24 & 48.00 & 82 & 54.67 \\
\hline Partly Satisfied & 02 & 4.00 & 05 & 10.00 & 01 & 2.00 & 08 & 5.33 \\
\hline Neutral & 00 & 00 & 00 & 00 & 01 & 2.00 & 01 & .67 \\
\hline Dissatisfied & 04 & 8.00 & 02 & 4.00 & 02 & 4.00 & 08 & 5.33 \\
\hline Total & 50 & 100 & 50 & 100 & 50 & 100 & 150 & 100 \\
\hline
\end{tabular}

(Source: Field Survey Report)

Table no. 1 shows that $34.00 \%$ of the respondents expressed the opinion that the connection fees of the sample mobile telecom companies is highly satisfied, $54.67 \%$ of the respondents thought that the connection fees is moderately satisfied, $5.33 \%$ of the respondents mentioned the opinion that the connection fees is partly satisfied, $0.67 \%$ of the respondents were neutral and $5.33 \%$ of the respondents opined that the connection fees is dissatisfied. Thus, the discussion shows that the majority respondents opined that the connection fees of the sample mobile telecom companies is moderately satisfied. 
In order to see whether there is any significant difference of opinions among the respondents regarding the connection fees and we conducted $\chi 2$ test and ANOVA test using SPSS. Accordingly we developed a null hypothesis which is:

$\mathrm{Ho}_{1}$ : There is no significant difference of opinion among the respondents regarding the connection fees of the sample mobile telecom operator companies.

By conducting the chi square test we observe that the value of $\chi^{2}$ is 11.165 which is significant at 0.193 level. So, our null hypothesis is accepted and we can conclude that there is no significant difference of opinions among the respondents regarding the connection fees of sample mobile telecom companies. We also conducted the ANOVA test and the results are given below:

Table No. 1.1: Table showing the results of ANOVA test regarding the connection fees of the sample mobile telecom operator companies

\begin{tabular}{|c|c|c|c|c|c|}
\hline & Sum of Squares & df & Mean Square & F & Sig. \\
\hline Between Groups & 1.773 & 2 & 0.8867 & 0.9927 & 0.3730 \\
\hline Within Groups & 131.300 & 147 & 0.8932 & & \\
\hline Total & 133.073 & 149 & & & \\
\hline
\end{tabular}

(Source: Field Survey Report)

Table No. 1.1 shows that $\mathrm{f}$ ratio is 0.9927 and its significance level is 0.3730 which means that there is no significant difference of opinions among the respondents regarding the connection fees of the mobile telecom operator companies in Bangladesh.

Table No. 2: Table showing the opinions of the respondents regarding the call rate of the sample mobile telecom operator companies

\begin{tabular}{|c|c|c|c|c|c|c|c|c|}
\hline & \multicolumn{3}{|c|}{ Respondents } & \multicolumn{3}{c|}{ Total } \\
\hline & \multicolumn{2}{|c|}{ Student } & \multicolumn{2}{c|}{ Business Man } & Service Holder & \multicolumn{3}{c|}{} \\
\hline & Frequency & $\%$ & Frequency & $\%$ & Frequency & $\%$ & Frequency & $\%$ \\
\hline Highly Satisfied & 15 & 30.00 & 18 & 36.00 & 14 & 28.00 & 47 & 31.34 \\
\hline Moderately Satisfied & 23 & 46.00 & 26 & 52.00 & 31 & 62.00 & 80 & 53.33 \\
\hline Partly Satisfied & 04 & 8.00 & 01 & 2.00 & 02 & 4.00 & 07 & 4.67 \\
\hline Neutral & 01 & 2.00 & 01 & 2.00 & 00 & 00 & 02 & 1.33 \\
\hline Dissatisfied & 07 & 14.00 & 04 & 8.00 & 03 & 6.00 & 14 & 9.33 \\
\hline Total & 50 & 100 & 50 & 100 & 50 & 100 & 150 & 100 \\
\hline
\end{tabular}

(Source: Field Survey Report)

Table no. 2 shows that $31.34 \%$ of the respondents thought that the call rate of the sample mobile telecom companies is highly satisfied, $53.33 \%$ of the respondents mentioned the opinion that the call rate is moderately satisfied, $4.67 \%$ of the respondents expressed the opinion that the call rate is partly satisfied, $1.33 \%$ of the respondents were neutral and $9.33 \%$ of the respondents opined that the call rate is dissatisfied. So, the discussion shows that the majority respondents expressed the opinion that the call rate of the sample mobile telecom companies is moderately satisfied.

In order to see whether there is any significant difference of opinions among the respondents regarding the call rate and we conducted $\chi 2$ test and ANOVA test using SPSS. Accordingly we developed a null hypothesis which is:

$\mathrm{Ho}_{2}$ : There is no significant difference of opinion among the respondents regarding the call rate of the sample mobile telecom operator companies. 
By conducting the chi square test we observe that the value of $\chi 2$ is 6.635 which is significant at 0.576 level. So, our null hypothesis is accepted and it is evident that there is no significant difference of opinions among the respondents regarding the call rate of sample mobile telecom companies. We also conducted the ANOVA test and the results are given below:

Table No. 2.1: Table showing the results of ANOVA test regarding the connection fees of the sample mobile telecom operator companies

\begin{tabular}{|c|c|c|c|c|c|}
\hline & Sum of Squares & df & Mean Square & F & Sig. \\
\hline Between Groups & 3 & 2 & 1.5 & 1.1934 & 0.3061 \\
\hline Within Groups & 184.76 & 147 & 1.2569 & & \\
\hline Total & 187.76 & 149 & & & \\
\hline
\end{tabular}

(Source: Field Survey Report)

Table No. 2.1 shows that the f ratio is 1.1934 and its significant level is 0.3061 which means that there is no significant difference of opinions among the respondents regarding the call rate of the mobile telecom operator companies in Bangladesh.

Table No. 3: Table showing the opinions of the respondents regarding the network facility of the sample mobile telecom operator companies

\begin{tabular}{|c|c|c|c|c|c|c|c|c|}
\hline & \multicolumn{4}{|c|}{ Respondents } & \multicolumn{3}{c|}{ Total } \\
\hline & \multicolumn{2}{|c|}{ Student } & \multicolumn{2}{c|}{ Business Man } & Service Holder & \multicolumn{3}{c|}{} \\
\hline & Frequency & $\%$ & Frequency & $\%$ & Frequency & $\%$ & Frequency & $\%$ \\
\hline Highly Satisfied & 29 & 58.00 & 32 & 64.00 & 26 & 52.00 & 87 & 58.00 \\
\hline Moderately Satisfied & 16 & 32.00 & 17 & 34.00 & 19 & 38.00 & 52 & 34.67 \\
\hline Partly Satisfied & 05 & 10.00 & 01 & 2.00 & 03 & 6.00 & 09 & 6.00 \\
\hline Neutral & 00 & 00 & 00 & 00 & 02 & 4.00 & 02 & 1.33 \\
\hline Dissatisfied & 00 & 00 & 00 & 00 & 00 & 00 & 00 & 00 \\
\hline Total & 50 & 100 & 50 & 100 & 50 & 100 & 150 & 100 \\
\hline
\end{tabular}

(Source: Field Survey Report)

Table no. 3 shows that $58.00 \%$ of the respondents expressed the opinion that the network facility of the sample mobile telecom companies is highly satisfied, $34.67 \%$ of the respondents mentioned the opinion that the network facility is moderately satisfied, $6.00 \%$ of the respondents opined that the network facility is partly satisfied, $.1 .33 \%$ of the respondents were neutral and none of the respondents opined that the network facility is dissatisfied. From the discussion it is evident that the majority respondents thought that the network facility of the sample mobile telecom companies is highly satisfied.

In order to see whether there is any significant difference of opinions among the respondents regarding the network facility and we conducted $\chi^{2}$ test and ANOVA test using SPSS. Accordingly we developed a null hypothesis which is:

$\mathrm{Ho}_{3}$ : There is no significant difference of opinions among the respondents regarding the network facility of the sample mobile telecom operator companies.

By conducting the chi square test we observe that the value of $\chi 2$ is 7.557 which is significant at 0.272 level. So, our null hypothesis is accepted and it is evident that there is no significant difference of opinions among the respondents regarding the network facility of sample mobile telecom companies. We also conducted the ANOVA test and the results are given below: 
Table No. 3.1: Table showing the results of ANOVA test regarding the network facility of the sample mobile telecom operator companies

\begin{tabular}{|c|c|c|c|c|c|}
\hline & Sum of Squares & df & Mean Square & F & Sig. \\
\hline Between Groups & 1.4533 & 2 & 0.7267 & 1.6175 & 0.2019 \\
\hline Within Groups & 66.04 & 147 & 0.4493 & & \\
\hline Total & 67.4933 & 149 & & & \\
\hline
\end{tabular}

(Source: Field Survey Report)

Table No. 3.1 shows that the f ratio is 1.6175 and its significant level is 0.2019 which means that there is no significant difference of opinions among the respondents regarding the network facility of the mobile telecom operator companies in Bangladesh.

Table No. 4: Table showing the opinions of the respondents regarding the various offers of the sample mobile telecom operator companies

\begin{tabular}{|c|c|c|c|c|c|c|c|c|}
\hline & \multicolumn{4}{|c|}{ Respondents } & \multicolumn{3}{c|}{ Total } \\
\hline & \multicolumn{2}{|c|}{ Student } & \multicolumn{2}{c|}{ Business Man } & Service Holder & \multicolumn{3}{c|}{} \\
\hline & Frequency & $\%$ & Frequency & $\%$ & Frequency & $\%$ & Frequency & $\%$ \\
\hline Highly Satisfied & 18 & 36.00 & 15 & 30.00 & 22 & 44.00 & 55 & 36.67 \\
\hline Moderately Satisfied & 28 & 56.00 & 31 & 62.00 & 25 & 50.00 & 84 & 56.00 \\
\hline Partly Satisfied & 04 & 8.00 & 02 & 4.00 & 01 & 2.00 & 07 & 4.67 \\
\hline Neutral & 00 & 00 & 00 & 00 & 00 & 00 & 00 & 00 \\
\hline Dissatisfied & 00 & 00 & 02 & 4.00 & 02 & 4.00 & 04 & 2.66 \\
\hline Total & 50 & 100 & 50 & 100 & 50 & 100 & 150 & 100 \\
\hline
\end{tabular}

(Source: Field Survey Report)

Table no. 4 shows that $36.67 \%$ of the respondents mentioned the opinion that the various offers of the sample mobile telecom companies is highly satisfied, $56.00 \%$ of the respondents thought that the various offers is moderately satisfied, $4.67 \%$ of the respondents expressed the opinion that the various offers is partly satisfied, .none of the respondents were neutral and $2.66 \%$ of the respondents opined that the various offers is dissatisfied. Thus, the discussion shows that the majority respondents thought that the various offers of the sample mobile telecom companies is moderately satisfied.

In order to see whether there is any significant difference of opinions among the respondents regarding the various offers and we conducted $\chi 2$ test and ANOVA test using SPSS. Accordingly we developed a null hypothesis which is:

$\mathrm{Ho}_{4}$ : There is no significant difference of opinions among the respondents regarding the various offers of the sample mobile telecom operator companies.

By conducting the chi square test we observe that the value of $\chi 2$ is 5.988 which is significant at 0.425 level. So, our null hypothesis is accepted and we can conclude that there is no significant difference of opinions among the respondents regarding the various offers of sample mobile telecom companies. We also conducted the ANOVA test and the results are given below:

Table No. 4.1: Table showing the results of ANOVA test regarding the various offers of the sample mobile telecom operator companies

\begin{tabular}{|c|c|c|c|c|c|}
\hline & Sum of Squares & df & Mean Square & F & Sig. \\
\hline Between Groups & 0.76 & 2 & 0.38 & 0.6305 & 0.5338 \\
\hline Within Groups & 88.6 & 147 & 0.6027 & & \\
\hline Total & 89.36 & 149 & & & \\
\hline
\end{tabular}

(Source: Field Survey Report) 
Table No. 4.1: shows that the $\mathrm{f}$ ratio is 0.6305 and its significant level is 0.5338 which means that there is no significant difference of opinions among the respondents regarding the various offers of the mobile telecom operator companies in Bangladesh.

Table No. 5: Table showing the opinions of the respondents regarding the balance transfer system of the sample mobile telecom operator companies

\begin{tabular}{|c|c|c|c|c|c|c|c|c|}
\hline & \multicolumn{9}{|c|}{ Respondents } & \multicolumn{3}{c|}{ Total } \\
\hline & \multicolumn{2}{|c|}{ Student } & \multicolumn{2}{c|}{ Business Man } & Service Holder & \multicolumn{3}{c|}{} \\
\hline & Frequency & $\%$ & Frequency & $\%$ & Frequency & $\%$ & Frequency & $\%$ \\
\hline Highly Satisfied & 20 & 40.00 & 26 & 52.00 & 28 & 56.00 & 74 & 49.33 \\
\hline Moderately Satisfied & 24 & 48.00 & 19 & 38.00 & 10 & 20.00 & 53 & 35.33 \\
\hline Partly Satisfied & 02 & 4.00 & 00 & 00 & 07 & 14.00 & 09 & 6.00 \\
\hline Neutral & 00 & 00 & 04 & 8.00 & 05 & 10.00 & 09 & 6.00 \\
\hline Dissatisfied & 04 & 8.00 & 01 & 2.00 & 00 & 00 & 05 & 3.34 \\
\hline Total & 50 & 100 & 50 & 100 & 50 & 100 & 150 & 100 \\
\hline
\end{tabular}

(Source: Field Survey Report)

Table no. 5 shows that $49.33 \%$ of the respondents expressed the opinion that the balance transfer system of the sample mobile telecom companies is highly satisfied, $35.33 \%$ of the respondents thought that the balance transfer system is moderately satisfied, $6.00 \%$ of the respondents mentioned the opinion that the balance transfer system is partly satisfied, $6.00 \%$ of the respondents were neutral and $3.34 \%$ of the respondents opined that the balance transfer system is dissatisfied. This Table also shows that the majority respondents expressed the opinion that the balance transfer system of the sample mobile telecom companies is moderately satisfied.

In order to see whether there is any significant difference of opinions among the respondents regarding the balance transfer system and we conducted $\chi 2$ test and ANOVA test using SPSS. Accordingly we developed a null hypothesis which is:

$\mathrm{Ho}_{5}$ : There is no significant difference of opinions among the respondents regarding the balance transfer system of the sample mobile telecom operator companies.

By conducting the chi square test we observe that the value of $\chi 2$ is 25.637 which is significant at 0.001 level. So, our null hypothesis is rejected and it is evident that there is significant difference of opinions among the respondents regarding the balance transfer system of sample mobile telecom companies. We also conducted the ANOVA test and the results are given below:

Table No. 5.1: Table showing the results of ANOVA test regarding the balance transfer system of the sample mobile telecom operator companies

\begin{tabular}{|c|c|c|c|c|c|}
\hline & Sum of Squares & df & Mean Square & F & Sig. \\
\hline Between Groups & 0.8133 & 2 & 0.4067 & 0.3823 & 0.6830 \\
\hline Within Groups & 156.36 & 147 & 1.0637 & & \\
\hline Total & 157.1733 & 149 & & & \\
\hline
\end{tabular}

(Source: Field Survey Report)

Table No. 5.1 shows that the $\mathrm{f}$ ratio is 0.3823 and its significant level is 0.6830 which means that there is no significant difference of opinions among the respondents regarding the balance transfer system of the mobile telecom operator companies in Bangladesh. 
Table No. 6: Table showing the opinions of the respondents regarding the FnF system of the sample mobile telecom operator companies

\begin{tabular}{|c|c|c|c|c|c|c|c|c|}
\hline & \multicolumn{4}{|c|}{ Respondents } & \multicolumn{3}{c|}{ Total } \\
\hline & \multicolumn{2}{|c|}{ Student } & \multicolumn{2}{c|}{ Business Man } & Service Holder & \multicolumn{3}{c|}{} \\
\hline & Frequency & $\%$ & Frequency & $\%$ & Frequency & $\%$ & Frequency & $\%$ \\
\hline Highly Satisfied & 24 & 48.00 & 25 & 50.00 & 19 & 38.00 & 68 & 45.33 \\
\hline Moderately Satisfied & 17 & 34.00 & 20 & 40.00 & 26 & 52.00 & 63 & 42.00 \\
\hline Partly Satisfied & 04 & 8.00 & 00 & 00 & 02 & 4.00 & 06 & 4.00 \\
\hline Neutral & 02 & 4.00 & 00 & 00 & 01 & 2.00 & 03 & 2.00 \\
\hline Dissatisfied & 03 & 6.00 & 05 & 10.00 & 02 & 4.00 & 10 & 6.67 \\
\hline Total & 50 & 100 & 50 & 100 & 50 & 100 & 150 & 100 \\
\hline
\end{tabular}

(Source: Field Survey Report)

Table no.6 shows that $45.33 \%$ of the respondents thought that the FnF system of the sample mobile telecom companies is highly satisfied, $42.00 \%$ of the respondents opined that the FnF system is moderately satisfied, $4.00 \%$ of the respondents mentioned the opinion that the FnF system is partly satisfied, $2.00 \%$ of the respondents were neutral and $6.67 \%$ of the respondents thought that the FnF system is dissatisfied. Thus, the discussion shows that the majority respondents expressed the opinion that the FnF system of the sample mobile telecom companies is highly satisfied.

In order to see whether there is any significant difference of opinions among the respondents regarding the FnF system and we conducted $\chi 2$ test and ANOVA test using SPSS. Accordingly we developed a null hypothesis which is:

Ho6: There is no significant difference of opinions among the respondents regarding the FnF system of the sample mobile telecom operator companies.

By conducting the chi square test we observe that the value of $\chi 2$ is 10.312 which is significant at 0.244 level. So, our null hypothesis is accepted and it is evident that there is no significant difference of opinions among the respondents regarding the FnF system of sample mobile telecom companies. We also conducted the ANOVA test and the results are given below:

Table No. 6.1: Table showing the results of ANOVA test regarding the FnF system of the sample mobile telecom operator companies

\begin{tabular}{|c|c|c|c|c|c|}
\hline & Sum of Squares & df & Mean Square & F & Sig. \\
\hline Between Groups & 0.0933 & 2 & 0.0467 & 0.0400 & 0.9608 \\
\hline Within Groups & 171.4 & 147 & 1.1660 & & \\
\hline Total & 171.4933 & 149 & & & \\
\hline
\end{tabular}

(Source: Field Survey Report)

Table No. 6.1 shows that the f ratio is 0.0400 and its significant level is 0.9608 which means that there is no significant difference of opinions among the respondents regarding the FnF system of the mobile telecom operator companies in Bangladesh. 
Table No. 7: Table showing the opinions of the respondents regarding the billing system of the sample mobile telecom operator companies

\begin{tabular}{|c|c|c|c|c|c|c|c|c|}
\hline & \multicolumn{7}{|c|}{ Respondents } & \multicolumn{2}{c|}{ Total } \\
\hline & \multicolumn{2}{|c|}{ Student } & \multicolumn{2}{|c|}{ Business Man } & Service Holder & \multicolumn{2}{c|}{} \\
\hline & Frequency & $\%$ & Frequency & $\%$ & Frequency & $\%$ & Frequency & $\%$ \\
\hline Highly Satisfied & 10 & 20.00 & 29 & 58.00 & 36 & 72.00 & 75 & 50.00 \\
\hline Moderately Satisfied & 35 & 70.00 & 16 & 32.00 & 11 & 22.00 & 62 & 41.33 \\
\hline Partly Satisfied & 00 & 00 & 00 & 00 & 03 & 6.00 & 03 & 2.00 \\
\hline Neutral & 05 & 10.00 & 05 & 10.00 & 00 & 00 & 10 & 6.67 \\
\hline Dissatisfied & 00 & 00 & 00 & 00 & 00 & 00 & 00 & 00 \\
\hline Total & 50 & 100 & 50 & 100 & 50 & 100 & 150 & 100 \\
\hline
\end{tabular}

(Source: Field Survey Report)

Table no. 7 shows that $50.00 \%$ of the respondents expressed the opinion that the billing system of the sample mobile telecom companies is highly satisfied, $41.33 \%$ of the respondents thought that the billing system is moderately satisfied, $2.00 \%$ of the respondents mentioned the opinion that the billing system is partly satisfied, $6.67 \%$ of the respondents were neutral and none of the respondents thought that the billing system is dissatisfied. Thus, the discussion shows that the majority respondents mentioned the opinion that the billing system of the sample mobile telecom companies is moderately satisfied.

In order to see whether there is any significant difference of opinions among the respondents regarding the billing system and we conducted $\chi 2$ test and ANOVA test using SPSS. Accordingly we developed a null hypothesis which is:

$\mathrm{Ho}_{7}$ : There is no significant difference of opinions among the respondents regarding the billing system of the sample mobile telecom operator companies.

By conducting the chi square test we observe that the value of $\chi 2$ is 44.234 which is significant at 0.000 level. So, our null hypothesis is rejected and we can conclude that there is significant difference of opinions among the respondents regarding the billing system of sample mobile telecom companies. We also conducted the ANOVA test and the results are given below:

Table No. 7.1: Table showing the results of ANOVA test regarding the billing system of the sample mobile telecom operator companies

\begin{tabular}{|c|c|c|c|c|c|}
\hline & Sum of Squares & $\mathrm{df}$ & Mean Square & $\mathrm{F}$ & Sig. \\
\hline Between Groups & 9.2133 & 2 & 4.6067 & 6.6534 & 0.0017 \\
\hline Within Groups & 101.78 & 147 & 0.6924 & & \\
\hline Total & 110.9933 & 149 & & & \\
\hline
\end{tabular}

(Source: Field Survey Report)

Table No. 7.1 shows that the f ratio is 6.6534 and its significant level is 0.0017 which means that there is significant difference of opinions among the respondents regarding the billing system of the mobile telecom operator companies in Bangladesh. 
Table No. 8: Table showing the opinions of the respondents regarding the service system of customer care centre of the sample mobile telecom operator companies

\begin{tabular}{|c|c|c|c|c|c|c|c|c|}
\hline & \multicolumn{7}{|c|}{ Respondents } & \multicolumn{2}{c|}{ Total } \\
\hline & \multicolumn{2}{|c|}{ Student } & \multicolumn{2}{|c|}{ Business Man } & Service Holder & \multicolumn{2}{c|}{} \\
\hline & Frequency & $\%$ & Frequency & $\%$ & Frequency & $\%$ & Frequency & $\%$ \\
\hline Highly Satisfied & 19 & 38.00 & 25 & 50.00 & 16 & 32.00 & 60 & 40.00 \\
\hline Moderately Satisfied & 22 & 44.00 & 20 & 40.00 & 31 & 62.00 & 73 & 48.67 \\
\hline Partly Satisfied & 04 & 8.00 & 01 & 2.00 & 00 & 00 & 05 & 3.33 \\
\hline Neutral & 01 & 2.00 & 02 & 4.00 & 03 & 6.00 & 06 & 4.00 \\
\hline Dissatisfied & 04 & 8.00 & 02 & 4.00 & 00 & 00 & 06 & 4.00 \\
\hline Total & 50 & 100 & 50 & 100 & 50 & 100 & 150 & 100 \\
\hline
\end{tabular}

(Source: Field Survey Report)

Table no. 8 shows that $40.00 \%$ of the respondents expressed the opinion that the service system of customer care centre of the sample mobile telecom companies is highly satisfied, $48.67 \%$ of the respondents thought that the service system of customer care centre is moderately satisfied, $3.33 \%$ of the respondents mentioned the opinion that the service system of customer care centre is partly satisfied, $4.00 \%$ of the respondents were neutral and $4.00 \%$ of the respondents presented the opinion that the service system of customer care centre is dissatisfied. Thus, the discussion shows that the majority respondents expressed the opinion that the service system of customer care centre of the sample mobile telecom companies is moderately satisfied.

In order to see whether there is any significant difference of opinions among the respondents regarding the service system of customer care centre and we conducted $\chi^{2}$ test and ANOVA test using SPSS. Accordingly we developed a null hypothesis which is:

Ho8: There is no significant difference of opinions among the respondents regarding the service system of customer care centre of the sample mobile telecom operator companies.

By conducting the chi square test we observe that the value of $\chi 2$ is 15.122 which is significant at 0.057 level. So, our null hypothesis is rejected and it is evident that there is significant difference of opinions among the respondents regarding the service system of customer care centre of sample mobile telecom companies. We also conducted the ANOVA test and the results are given below:

Table No. 8.1: Table showing the results of ANOVA test regarding the service system of customer care centre of the sample mobile telecom operator companies

\begin{tabular}{|c|c|c|c|c|c|}
\hline & Sum of Squares & $\mathrm{df}$ & Mean Square & $\mathrm{F}$ & Sig. \\
\hline Between Groups & 1.7733 & 2 & 0.8867 & 0.9510 & 0.3887 \\
\hline Within Groups & 137.06 & 147 & 0.9324 & & \\
\hline Total & 138.8333 & 149 & & & \\
\hline
\end{tabular}

(Source: Field Survey Report)

Table No. 8.1 shows that the $\mathrm{f}$ ratio is 0.9510 and its significant level is 0.3887 which means that there is no significant difference of opinions among the respondents regarding the service system of customer care centre of the mobile telecom operator companies in Bangladesh. 
Table No. 9: Table showing the opinions of the respondents regarding the connection charges of internet service of the sample mobile telecom operator companies

\begin{tabular}{|c|c|c|c|c|c|c|c|c|}
\hline & \multicolumn{9}{|c|}{ Respondents } & \multicolumn{2}{c|}{ Total } \\
\hline & \multicolumn{2}{|c|}{ Student } & \multicolumn{2}{|c|}{ Business Man } & \multicolumn{2}{c|}{ Service Holder } & \multicolumn{2}{c|}{} \\
\hline & Frequency & $\%$ & Frequency & $\%$ & Frequency & $\%$ & Frequency & $\%$ \\
\hline Highly Satisfied & 20 & 40.00 & 24 & 48.00 & 27 & 54.00 & 71 & 47.34 \\
\hline Moderately Satisfied & 24 & 48.00 & 19 & 38.00 & 18 & 36.00 & 61 & 40.67 \\
\hline Partly Satisfied & 02 & 4.00 & 06 & 12.00 & 00 & 00 & 08 & 5.33 \\
\hline Neutral & 00 & 00 & 00 & 00 & 02 & 4.00 & 02 & 1.33 \\
\hline Dissatisfied & 04 & 8.00 & 01 & 2.00 & 03 & 6.00 & 08 & 5.33 \\
\hline Total & 50 & 100 & 50 & 100 & 50 & 100 & 150 & 100 \\
\hline
\end{tabular}

(Source: Field Survey Report)

Table no. 9 shows that $47.34 \%$ of the respondents mentioned the opinion that the connection charges of internet service of the sample mobile telecom companies is highly satisfied, $40.67 \%$ of the respondents thought that the connection charges of internet service is moderately satisfied, $5.33 \%$ of the respondents opined that the connection charges of internet service is partly satisfied, $1.33 \%$ of the respondents were neutral and $5.33 \%$ of the respondents presented the opinion that the connection charges of internet service is dissatisfied. This discussion shows that the majority respondents thought that the connection charges of internet service of the sample mobile telecom companies is moderately satisfied.

In order to see whether there is any significant difference of opinions among the respondents regarding the connection charges of internet service and we conducted $\chi 2$ test and ANOVA test using SPSS. Accordingly we developed a null hypothesis which is:

Hog: There is no significant difference of opinions among the respondents regarding the connection charges of internet service of the sample mobile telecom operator companies.

By conducting the chi square test we observe that the value of $\chi 2$ is 14.809 which is significant at 0.063 level. So, our null hypothesis is accepted and it is evident that there is no significant difference of opinions among the respondents regarding the connection charges of internet service of sample mobile telecom companies. We also conducted the ANOVA test and the results are given below:

Table No. 9.1: Table showing the results of ANOVA test regarding the connection charges of internet service of the sample mobile telecom operator companies

\begin{tabular}{|c|c|c|c|c|c|c|}
\hline & & Sum of Squares & df & Mean Square & F & Sig. \\
\hline RESPONSE & Between Groups & 0.6533 & 2 & 0.3267 & 0.2812 & 0.7552 \\
\hline & Within Groups & 170.74 & 147 & 1.1615 & & \\
\hline & Total & 171.3933 & 149 & & & \\
\hline
\end{tabular}

(Source: Field Survey Report)

Table No 9.1 shows that the $\mathrm{f}$ ratio is 0.2812 and its significant level is 0.7552 which means that there is no significant difference of opinions among the respondents regarding the connection charges of internet service of the mobile telecom operator companies in Bangladesh.

\section{ConcLusion}

This present research study discloses the customer satisfaction regarding the different services of the mobile telecom operator companies in Bangladesh. Day by day the general life style of the people is becoming more complex and for that the services of mobile telecom operator companies is necessary for the upper level to lower level people to introduce with the global world. In this situation mobile telecom has become a popular and easy 
communication system to the mass people. Customer satisfaction is the vital issues of the every mobile telecom operator companies because there is no scope to reach desired level of every mobile telecom operator companies in Bangladesh without customers' satisfaction. The study has considered some factors for measuring the customer satisfaction regarding the different services of mobile telecom operator companies such as connection fees, call rate, network facility, various offers, balance transfer system, FnF system, billing system, service system of customer care centre and connection charges of internet service and these factors are related with customers behavior. In this present study the selected respondents were directly involved to give their opinions regarding the different services of mobile telecom companies and it is evident that the most of the respondents have given opinions about moderately satisfaction regarding the different services. This present research study has developed some hypotheses for analysis the collected opinions of the selected respondents and most of the null hypotheses are accepted which means that there is no significant difference of opinions among the respondents regarding the different services of the mobile telecom operator companies in Bangladesh. Maintaining desired level of customer satisfaction mobile telecom operator companies should pay attention for improving the quality of different services and customer image.

\section{REFERENCES}

Ahmed AA and Ahmad M. 2009. An Empirical Analysis of Performance Measurement of the Disclosure in Financial Reporting: A Study of Banking Sector in Bangladesh COMSATS Institute if Information Technology 2nd COMSATS International Business Research Conference. Lahore, Pakistan: CIIT.

Ahmed AA and Neogy TK. 2009. Merger \& Acquisitions (M\&A) Goodwill Accounting: Principles and Practice The Bangladesh Accountant, 65, Oct-Dec.

Ahmed AA and Neogy TK. 2010. Forensic Accounting in Bangladesh: Emergence and Introduction Development Compilation, 3, 71-82.

Ahmed AA and Siddique MN. 2013. Internet Banking Espousal in Bangladesh: A Probing Study Engineering International, 1, 40-47.

Ahmed, J., \& Rouf, M. (2014). Controlled, Uncontrolled Communication, Brand Name and Brand Attitude: A Relational Study on Cellular Telecom Sector of Bangladesh. American Journal Of Trade And Policy, 1(3), 102-108.

Alam, N., \& Rubel, A. (2014). Impacts of Corporate Social Responsibility on Customer Satisfaction in Telecom Industry of Bangladesh. ABC Journal Of Advanced Research, 3(2), 26-37.

Ashaduzzaman, M., Ahmed, S. M. S. and Khan, M. M. (2011), “Consumer Choice Behavior towards Mobile Phone Operators in Bangladesh", Journal of Arts, Science \& Commerce, Vol. II, Issue-4, October, pp. 30-39.

Chowdhury, M. (2015). Socio-Economic Impacts of Mobile Penetration in SAARC Countries with Special Emphasis on Bangladesh. Asian Business Review, 5(2), 66-71.

Chowdhury, M., \& Rahman, M. (2015). Consumer Attitude Towards the Cell Phone: A study on Young Generations of Chittagong Metropolitan City, Bangladesh. Asian Business Review, 3(3), 16-20.

Hoque, M., Karim, M., \& Amin, M. (2015). Factors Affecting the Adoption of mHealth Services among Young Citizen: A Structural Equation Modeling (SEM) Approach. Asian Business Review, $5(2), 60-65$.

Hossain, M. S., Hossain, M. A. and Siddikee, M. J. A. (2012), “The Drivers of Customers' Satisfaction of Airtel Bangladesh Limited", Bangladesh Researcher Publications Journal, Volume 7, Issue 4, November-December, pp. 437-445.

Islam, K., \& Salma, U. (2014). Customer Satisfaction of Internet Banking in Bangladesh: A Case Study on Citibank N.A. Asian Journal Of Applied Science And Engineering, 3(1), 51-62. 
Kabir, M. R., Alam, M. M. D. and Alam, Z. (2009), “Factors determining the Customer Satisfaction \& Loyalty: A Study of Mobile Telecommunication Industry in Bangladesh", ASA University Review, Vol. 3, No. 2, July-December, pp. 147-156.

Masud-Ul-Hasan, M., Rahman, M., \& Rana, M. (2015). Identifying Service Quality Attributes and Measuring Customer Satisfaction of Dhaka-Pabna Route Public Bus Service. Asian Business Review, 5(2), 72-78.

Neogy, T. (2014). Evaluation of the Companies' Performance: A Study on Mobile Telecommunication Companies in Bangladesh. American Journal Of Trade And Policy, 1(2), 79-84.

Neogy, T. (2015). Evaluation of the Legal Framework and Accounting Standards: A Study on Mobile Telecommunication Companies in Bangladesh. ABC Journal Of Advanced Research, 4(1), 27-38.

Neogy, T. K. (2013), “Disclosure Practices of Mobile Telecommunication Companies with Special Reference to Grameenphone Ltd.”, Global Disclosure of Economics and Business, Volume 2, No. 1, pp. 61-75.

Neogy, T. K., Ghosh, S. K. and Amin, M. R. (2013), “Financial Statement Analysis of Grameenphone Ltd. in Bangladesh: An Evaluation", Banglavision Research Journal, Vol. 12, No. 1, pp. 47-58.

Rahman, et. al. (2014), “Factors Affecting Customer Satisfaction on Grameenphone Users in Bangladesh", Global Journal of Management and Business Research: E Marketing, Volume 14, Issue 3, pp. 56-66.

Rahman, M. S. (2012), “Service Quality, Corporate Image and Customer's Satisfaction towards Customers Perception: An Exploratory Study on Telecom Customers in Bangladesh", Business Intelligence Journal, Vol. 5, No. 1, January, pp. 56-63.

Rahman, M. T. (2010), "Making Teletalk a healthy competitor among the mobile phone operators in Bangladesh", Journal of Business and Technology (Dhaka), Vol. 5. Issue 2, July-December

Rahman, S., \& Masoom, M. (2015). Effects of Relationship Marketing on Customer Retention and Competitive Advantage: A Case Study on Grameen Phone Ltd.. Asian Business Review, 1(2), 97-102.

Roy, P. (2013). Wireless Internet Service and Customer Satisfaction: A Case Study on Young Generation in Bangladesh. Asian Journal Of Applied Science And Engineering, 2(2), 96-102.

Sabur, M. (2015). Total Quality Management as a Tool for Decision Making. Asian Business Review, $3(4), 121-125$.

Saha, A., Hasan, K., \& Uddin, M. (2014). A Conceptual Framework for Understanding Customer Satisfaction in Banking Sector: The Mediating Influence of Service Quality and Organizational Oath. American Journal Of Trade And Policy, 1(2), 85-93.

Sheth, J. N. (2001), “Competitive Advantages through Customer Satisfaction”, BMA Review, 2, pp. 13-25

Siddique, M. N., Akterujjaman, S. M. and Perveen, R. (2012), “Customers' Satisfaction towards the Services of Customer Care Centers of Grameenphone: A Study on Dhaka and Khulna Cities”, ASA University Review, Vol. 6, No. 2, July-December, pp. 45-60.

Website of Bangladesh Telecommunication Regulatory Commission (BTRC).

Website of Banglalink Digital Communications Limited (Banglalink) and Robi Axiata Limited (Robi).

Yadav, R. K. and Dabhade, N. (2013), "Impact of Services Quality on Customer Satisfaction of Mobile Users - A Case Study of Airtel", International Journal of Innovative Researcher E Studies, Vol. 2, Issue 5, pp. 139-163. 